\title{
Lateral periodontal kist tedavisinde yönlendirilmiş doku rejenerasyonu: Bir olgu sunumu
}

\author{
Emre Yaprak ${ }^{1}$, Sibel Kayaaltı Yüksek ${ }^{1}$, Bahar Müezzinoğlu², Cansu Gür İlgen ${ }^{3}$, Alper Sinanoğlu ${ }^{4}$
}

Selcuk Dent J, 2016; 3: 140-144

Başvuru Tarihi: 11 Ocak 2016 Yayına Kabul Tarihi: 24 Haziran 2016

\begin{abstract}
Öz
Lateral periodontal kist tedavisinde yönlendirilmiş doku rejenerasyonu: Bir olgu sunumu

Lateral periodontal kist (LPK), nadir görülen bir gelişimse odontojenik kist türüdür. Klinik olarak semptomsuzdur, fakat bazen dişetinde şişlik görülebilir. Genelde yetişkinlerin mandibular kanin ve premolar bölgesinde izlenir. Bu vaka raporunda, lateral periodontal kist teşhisi konmuş bir hastanın tedavisi sunulmaktadır. Sağ mandibular kanin ve premolar bölgesinde ağrısız şişlik şikayeti ile başvuran 41 yaşındaki bayan hastaya, klinik ve radyografik değerlendirmeler sonucunda lateral periodontal kist teşhisi kondu. Tedavi planı olarak, kist bölgesinin cerrahi olarak enükleasyonu ve eş zamanlı yönlendirilmiş doku rejenerasyonu amac ile kemik grefti ve membran uygulaması planlandı. İlgili tedaviler sonrası 6 aylık takip sürecinde nüks izlenmedi ve ilgili bölgede radyolojik kemik dolumu görüldü. Histopatolojik inceleme sonucunda klinik ön tanı doğrulandı.
\end{abstract}

\section{ANAHTAR KELIMELER}

Lateral periodontal kist, periodontal tedavi, yönlendirilmiş doku rejenerasyonu

Lateral periodontal kist (LPK), çoğunlukla mandibular kanin ve premolar bölgede ve daha az sıklıkla anterior bölgede lokalize olan nadir görülen çenelerin gelişimsel odontojenik kistidir. Çenelerde görülen kistlerin \% 0.7-\% 1'ini oluşturur. Daha çok erişkinlerde görülür (Moskow ve ark. 1970, Kreidler ve ark. 1993). Patolojisi tam olarak bilinmemekle beraber mine epiteli, malessez hücre kalıntıları veya dental lamina artıklarından köken aldığı düşünülmektedir (Altini ve Shear 1992). LPK, sekonder olarak enfekte olmadığı sürece genellikle semptomsuzdur ve ilişkili olduğu diş vitaldir. Alveol kemiğinde genişlediği zaman klinik olarak gözlenebilir. Klinik olarak genellikle normal görünen alveol mukozanın örttüğü sıkı, kubbe şeklinde ve hareketsiz bir şişlik olarak görülür.

\section{ABSTRACT}

Guided tissue regeneration for lateral periodontal cyst treatment: A case report

The lateral periodontal cyst (LPC), is a rare developmental odontogenic cyst. Clinically it presents may be symptomless, but occasionally a gingival swelling can be seen. It occurs most frequently in the mandibular canine-premolar region and in adults. This case report presents treatment of LPC. A 41year-old woman with a complaint painless swelling in the right mandibular canine-premolar region was diagnosed as LPF based on clinical and radiographic evaluations. The surgical enucleation with guided tissue regeneration technique was planned for treatment plan. After 6 months follow-up no signs of recurrence and evidence of bone formation was seen in lesion region. Clinical diagnosis was confirmed with histopathological evaluation.

\section{KEYWORDS}

Lateral periodontal cyst, periodontal treatment, guided tissue regeneration

Bununla birlikte, dokunun ekspansiyonu ile birlikte dokuda beyazlama veya kistin mavimsi-gri renk tonu olabilir. Genellikle, gingival sulkusun sondlanması ile kist kavitesi arasında ilişki yoktur. Ağrı ve parestezi nadir olarak görülmektedir (Cohen ve ark. 1984). Radyografik olarak ise, diş kökünün lateral yüzünde diş kökü ile alvolar kret arasında sınırları belirgin, yuvarlak veya gözyaşı damlası şeklinde, uniloküler radyolüsent lezyon olarak görülür. Lezyon tipik olarak küçük çaptadır ve nadiren $1 \mathrm{~cm}$ üzerindedir (Cohen ve ark. 1984, Rasmusson ve ark. 1991). Histolojik olarak kistik kavitenin iç yüzeyi non-keratinize çok katlı yassı epitel ile çevrilidir. Hücre sitoplazmaları glikojenden zengindir (Cohen ve ark. 1984, Angelopoulou ve

\footnotetext{
${ }^{1}$ Kocaeli Üniversitesi Diş Hekimliği Fakültesi Ağız Diş ve Çene Cerrahisi Anabilim Dalı, Kocaeli

${ }^{2}$ Kocaeli Üniversitesi Tıp Fakültesi, Patoloji Anabilim Dalı, Kocaeli

${ }^{3}$ Kocaeli Üniversitesi Diş Hekimliği Fakültesi Endodonti Anabilim Dalı, Kocaeli

${ }^{4}$ Kocaeli Üniversitesi Diş Hekimliği Fakültesi Ağı, Diş ve Çene Radyolojisi Anabilim Dalı, Kocaeli
} 
ark. 1990). Tedavisinde ise, genellikle kistin enükleasyonu yapılmaktadır. Fakat enükleasyondan sonra tam kemik rejenerasyonu sağlanmamaktadır. Özellikle estetiğin önemli olduğu bölgelerde yüksek oranda kemik dolumu sağlayan yönlendirilmiş kemik rejenerasyonu (YDR) uygulanabilmektedir (Lehrhaupt ve ark. 1997, Nart ve Gagari 2007). Bu vaka raporu, lateral periodontal kistin klinik bulgularını, kistin periapikal radyografi ve tomografi ile incelenmesini, histolojik bulgularını ve rejenaratif periodontal cerrahi ile tedavisini ve 6 aylık takip sonuçlarını sunmaktadır.

\section{OLGU SUNUMU}

Sistemik olarak sağlıklı 41 yaşındaki bayan hasta sağ alt çene bölgesi premolar dişleri bölgesindeki dişeti şişliği şikayeti ile Kocaeli Üniversitesi Diş Hekimliği Fakültesi Periodontoloji Anabilim Dalı'na başvurdu. Hastanın öyküsünden, dişetindeki büyümenin 5 ay boyunca kademeli olarak artış göstermiş olduğu öğrenildi. Hastanın ağız içi muayenesinde, 43-44 dişler bölgesinde, dişlerin kökleri hizasında yaklaşık $15 \mathrm{~mm}$ çapında fluktuan bir şişlik tespit edildi (Resim 1).

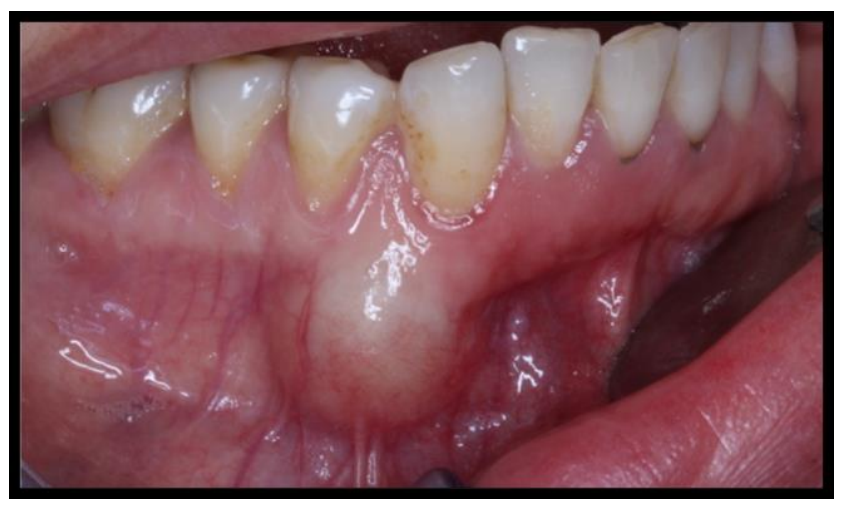

Resim 1.

Başlangıç ağız içi görünümü

İlgili dişler bölgesinde $2 \mathrm{~mm}$ 'den fazla sondlama derinliği gözlenmedi. Vitalometrik değerlendirme sonucunda dişlerin vital olduğu tespit edildi. İlgili bölgenin CBCT incelemesinde lezyonun bukkal kemik korteksini perfore ettiği fakat lingual korteksin bütünlüğünü koruduğu görüldü. İlgili dişlerin apeksleri CBCT kesitlerinde incelendiğinde lezyonun endodontik kaynaklı olmadığı değerlendirildi.

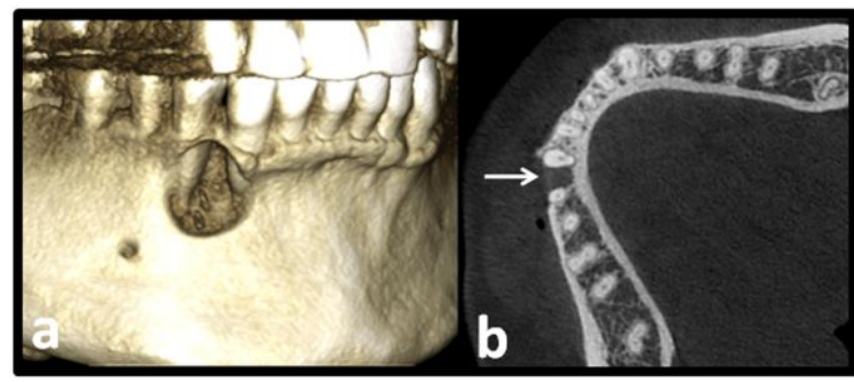

Resim 2.

a) Lezyonun 3 boyutlu görüntüsü

b) Horizontal kesitte lezyonun görüntüsü

Dişlerin vital olması da göz önünde bulundurularak, söz konusu lezyon lateral periodontal kist ön tanısı ile değerlendirilmeye alındı ve tedavi süreci başlatıldı (Resim 3). Tedavi planı kapsamında lateral periodontal kistin cerrahi olarak enükleasyonu ve defekt bölgesine YDR uygulanması planlandı. Faz I periodontal tedaviyi takiben, cerrahi tedaviler sonrasında sekonder endodontik sorunların önüne geçmek amacı ile 43 ve 44 no'lu dişlere kanal tedavileri yapıldı. Cerrahi uygulama sırasında ve operasyon sonrası erken iyileşme döneminde ilgili dişlerde mobilite artışının söz konusu olabileceği düşünülerek, 43 ve 44 no'lu dişlere geçici kompozit splint uygulandı.

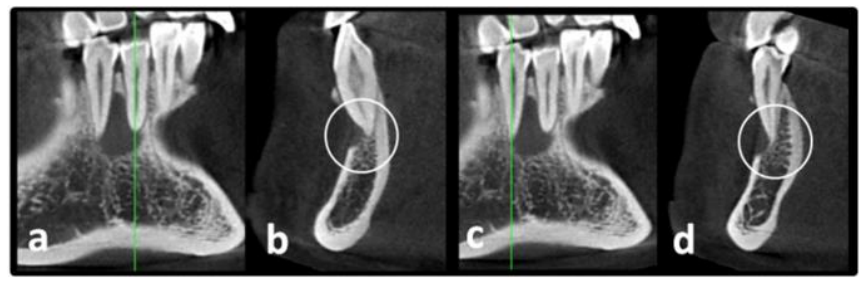

Resim 3.

a-b) 43 no'lu dişin CBCT kesiti

c-d) 44 no'lu dişin CBCT kesiti

\section{Cerrahi uygulama}

Bukkal destekli inferior alveoler blok anestezisini takiben, sulkuler insizyonlar vertikal insizyonlarla desteklenerek muko-periosteal flep kaldırıldı. Kist duvarı periodontal küretler ile alveol kemikten ve flebin iç kısmından nazikçe ayrıldı. Defekt bölgesindeki granülasyon dokusu kalıntıları uzaklaştıııldı (Resim 4a). İlgili dişlere kök yüzeyi düzleştirmesi işlemi uygulandı. Bölge serum fizyolojik ile yıkandıktan sonra sığır kaynaklı kemik grefti (Gen-Os, Teknos Dental, Italy) ve sığır kaynaklı kolajen membran (Gen-Oss, Dentium, Korea) uygulaması yapıldı (Resim 4b-4c). Flep 5/0 poliglaktik dikiş (Vicryl, Ethicon, Johnson \& Johnson, St-Stevens-Woluwe, Belgium) ile dikildi (Resim 4d). 


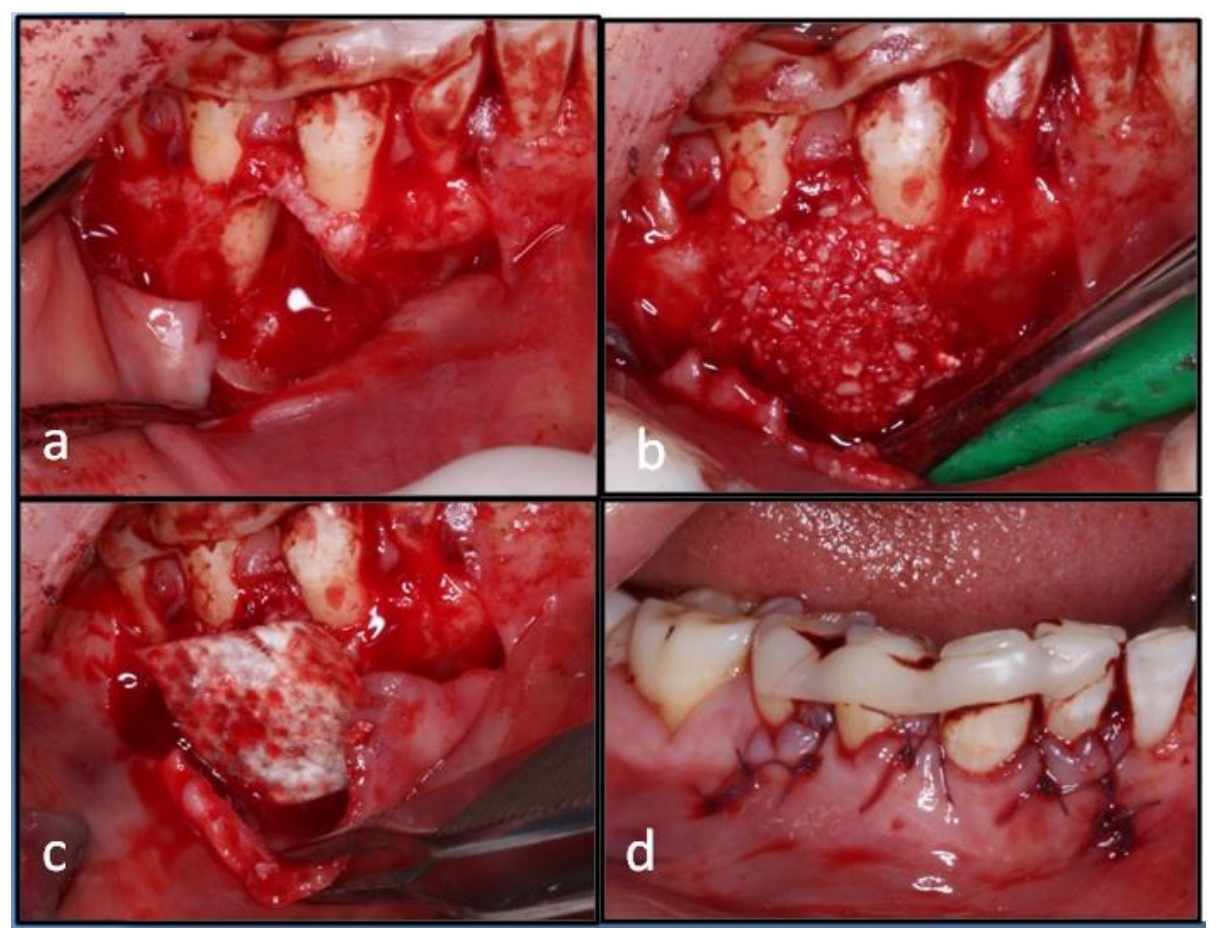

Resim 4.
A ) Kistin uzaklaştırılmasından sonra defektin görüntüsü
B ) Kemik grefti uygulaması
C ) Membranın alıcı bölgeye yerleştirilmesi
D ) Flebin kapatılması

Hastaya operasyon sonrası dikkat etmesi gerekenler anlatıldı. Antibiyotik (Amoksisilin $1000 \mathrm{mg} \mathrm{BID}$ ), analjezik (Flurbiprofen $100 \mathrm{mg}$ ) ve antiseptik ağız gargarası $(\% 0.12$ Klorheksidin diglukonat) reçete edildi. Hasta operasyon sonrası takip sürecine alındı. Histopatolojik inceleme sonucu elde edilen bulgular lateral periodontal kist ile uyumlu görüldü (Resim 5).

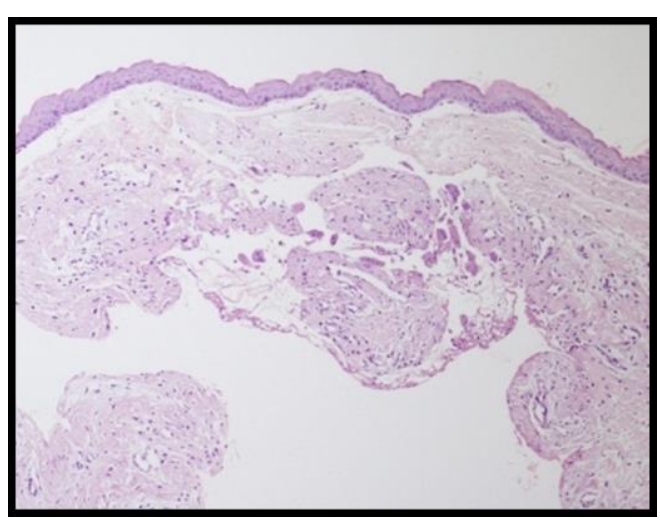

Resim 5.

Çok katlı yassı epitel ile döşeli, dağınık yabancı cisim dev hücreleri içeren fibröz cidara sahip kistik gelişim (X100 H\&E).
Operasyon sonrası 10. günde dikişler alındı. Operasyon sonrası 6 aylık süreçte her hangi bir olumsuzluğa rastlanmadı (Resim 6).

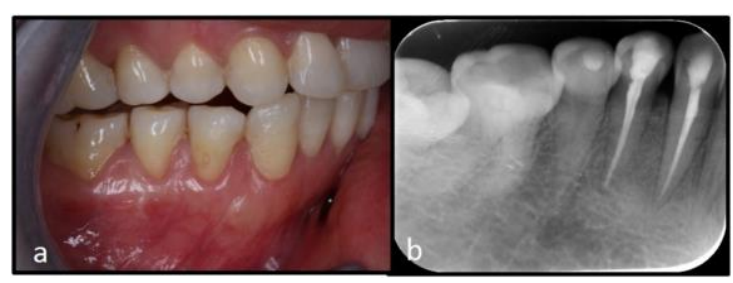

Resim 6.

Operasyon sonrası 6. aydaki klinik (a) ve radyografik (b) görüntü

\section{TARTIŞMA}

Lateral periodontal kist nadir görülmesine rağmen, klinik, radyografik ve histolojik özellikleri iyi tanımlanan bir odontojenik kist türüdür (Cohen ve ark. 1984, Angelopoulou ve ark. 1990). Literatür incelendiğinde, LPK tedavisinde enükleasyon yaklaşımın yaygın olarak uygulandığı görülmüştür. Kist enükleasyonunu takiben genellikle sorunsuz 
klinik iyileşme görüldüğü ve nadir olarak nüks görüldüğü bilinmektedir (Moskow ve ark. 1970, Cohen ve ark. 1984, Lehrhaupt ve ark. 1997, Friedrich ve ark. 2014). Bununla beraber, tam kemik dolumu için gerekli süre ile ilgili literatürde çok fazla bilgi yoktur. Ayrıca literatürde enükleasyonu takiben kemik iyileşmesi tam olarak açıklanmış değildir. Kist enükleasyonunu takiben kemik defektinin büyüklüğü ve anatomisi rejenerasyon potansiyelini etkileyerek tedavi başarısını düşürebilir. Kemik içi defektlerde YDR'nun, sadece cerrahi debridman ile tedaviye göre daha etkili sonuçlar verdiği bilinmektedir (Nart ve ark. 2007).

1997 yllında Nina ve arkadaşları, lateral periodontal kistin mandibular premolar bölgede bukkal ve lingual kortikal kemiği perfore ettiği bir vaka sunmuşlardır. Kistin enükleasyonundan sonra kemik defektinin büyüklüğünden dolayı, osteoindüktif ve osteokondüktif özelliklerinden yararlanmak için kemik defektini dekalsifiye dondurulmuş kurutulmuş kemik grefti ile doldurmuşlardır. 30 ay sonra alınan radyografta artmış radyoopasite gürülmüştür. Nüks ise görülmemiştir (Lehrhaupt ve ark. 1997).

Lateral periodontal kist tedavisinde YDR ilk kez 2007'de Nart ve arkadaşları tarafından uygulanmıştır (Nart ve ark. 2007). Mandibular sağ kanin ve premolar dişler arasında lokalize olan kistin tedavisinde, basit kist enükleasyonu yapılmışıı. Kalan bir duvarlı kemik defektinin düşük rejenerasyon potansiyelinden dolayı YDR planlanmış, allogreft ve sığır kaynaklı membran kullanılmıştır. 7 ay sonra defekt cerrahi olarak yeniden açıldığında yüksek oranda kemik dolumu gözlenmiştir. Nart ve arkadaşları, LPK tedavisinde basit enükleasyonu takiben YDR kullanımının ataçman kaybını azalttığını ve yüksek oranda kemik dolumu sağladığını savunmuşlardır.

2014 yılında Meşeli ve arkadaşları lateral periodontal kistin enükleasyonunu takiben membran kullanarak sığır kaynaklı ksenogreft uyguladıkları bir olgu sunumu yayınlamışlardır. Vaka 6 ay sonra değerlendirilmiş, tatmin edici klinik ve radyografik sonuçlar alınmıştır (Meşeli ve ark. 2014).

Bu vaka raporunda, LPK enükleasyonundan sonra kalan kemik defektinin büyük olması ve defektin anatomisinden dolayı YDR yaklaşımının uygulandığı başarılı bir periodontal kist tedavisi ve 6 aylık takibi sunulmuştur. Kemik defektinin büyük olduğu ve rejenerasyon potansiyelinin az olduğu düşünülen vakalarda YDR ile tedavinin uygun olabileceği düşünülmektedir. LPF tedavisinde, YDR kullanımının etkilerini değerlendiren ileri çalışmalara intiyaç vardır. 


\section{KAYNAKLAR}

Altini M, Shear M,1992. The lateral periodontal cyst: an update. J Oral Pathol Med, 21(6), 245-250.

Angelopoulou E, Angelopoulos AP, 1990. Lateral periodontal cyst. Review of the literature and report of a case. JPeriodontol, 61,126-131.

Cohen DA, Neville BW, Damm DD, White DK, 1984. The lateral periodontal cyst. A report of 37 cases. $J$ Periodontol, 55:230-234.

Friedrich RE, Scheuer HA, Zustin J, 2014. Lateral periodontal cyst. In Vivo, 28:595-598.

Kreidler JF, Raubenheimer EJ, van Heerden WF, 1993. A retrospective analysis of 367 cystic lesions of the jaw--the Ulm experience. J Craniomaxillofac Surg, 21, 339-441.

Lehrhaupt NB, Brownstein CN, Deasy MJ, 1997. Osseous repair of a lateral periodontal cyst. J Periodontol, 68,608-611.

Meseli SE, Agrali OB, Peker O, Kuru L, 2014. Treatment of lateral periodontal cyst with guided tissue regeneration. Eur J Dent, 8,419-423.

Nart J, Gagari E, Kahn MA, Griffin TJ, 1970. Use of guided tissue regeneration in the treatment of a lateral periodontal cyst with a 7-month reentry. J Periodontol 2007;78:1360-364.Moskow BS, Siegel K, Zegarelli EV, Kutscher AH, Rothenberg F. Gingival and lateral periodontal cysts. J Periodontol, 41, 249260.

Rasmusson LG, Magnusson BC, Borrman H, 1991. The lateral periodontal cyst. A histopathological and radiographic study of 32 cases. Br J Oral Maxillofac Surg, 29, 54-57.

Yazışma Adresi:

Emre YAPRAK

Kocaeli Üniversitesi

Diş Hekimliği Fakültesi

Periodontoloji Anabilim Dalı

Yuvacık, Başiskele, Kocaeli, Türkiye

Tel : +9026234422 22

Faks : +902623442109

E-mail: dt_emreyaprak@hotmail.com 